\title{
Variation in Soil Properties and Carbon Stocks under Roadside Plantation and Rice-Wheat Cropping System in North Western Haryana, India
}

\author{
Rahul Arya $^{1}$, Ajay Kumar Mishra ${ }^{2}$ and Smita Chaudhry ${ }^{1 *}$
}

${ }^{1}$ Institute of Environmental Studies, Kurukshetra University, Kurukshetra, Haryana, India

${ }^{2}$ Terrestrial Ecosystem Management Laboratory, Graduate School of Global Environmental Studies, Kyoto University, Kyoto, Japan

*Corresponding author

\section{A B S T R A C T}

Understanding ecological diversity and physicochemical properties of the soil is of core concern for better management of roadside plantation, especially in developing countries. Soil properties and carbon stocking are largely influenced by the landuse and spatial distribution. This study compares two different landuse, i.e., roadside plantation and rice-

\section{Keywords}

Land use, Carbon stock, Nutrient availability,

Ecological diversity,

Rice-wheat cropping

system

Article Info

Accepted:

16 March 2018

Available Online:

10 April 2018 wheat (RW) cropping system at five different locations (Ambala, Kurukshetra, Karnal, Panipatand Sonipat) to assess their effects on soil properties and carbon stocking as well as maintaining ecological diversity in North-Western (NW) Haryana, India. Our data showed that physicochemical properties of the soil varied among the landuse and sampling locations. Soil bulk density was significantly different in both the land use and ranged from 1.10 to $1.27 \mathrm{~g} \mathrm{~cm}^{-3}$ and 1.15 to $1.43 \mathrm{~g} \mathrm{~cm}^{-3}$ for roadside plantation and $\mathrm{RW}$ cropping system, respectively. Soil carbon stock increased by $51.1 \%$ in roadside plantation as compared to rice-wheat cropping system that substantially contributes towards carbon sequestration in the soil. Available Nitrogen in the agricultural soils is statistically higher as compared to the roadside plantation. Principal component analysis of landuse and sampling sites showed variability in the soil properties suggesting the effect of soil management. Higher ecological diversity in roadside plantation improved the physicochemical properties by diverse organic inputs. The study highlights the importance of roadside plantation comparative to rice wheat cropping system in improving soil properties and sequestering carbon.

\section{Introduction}

In India, human population has increased sixfold from 200 million to 1200 million that coupled with economic growth has resulted in significant land use and land cover changes during 1880-2010 (Tian et al., 2014). Such enormous pressure of population explosion leads to rapid deforestation of tropical forest in India to compensate per capita availability of land. To maintain the ecological balance and natural cycling, we need to explore other viable options for the tree outside forests (TOF). TOF as plantation forestry plays a significant role in many ways like increasing aesthetic, ecological and environmental safeguard. Plantation forestry such as roadside plantation, block plantation is a low-cost 
mitigation strategy for reducing the global carbon emissions and maintaining ecological diversity. Furthermore, plantation forestry improves the soil health by maintaining the soil fertility through its vast and diverse organic input into the soil (Kumar et al., 2014; Chaudhari et al., 2015b) and is known to bring changes in edaphic, microclimatic, floral, faunal and other components of the ecosystem through bio-recycling of mineral elements, environmental modifications and changes in floral and faunal composition (Shukla 2009). Meagre and ambiguous information is available on the changes in physicochemical properties and carbon stocking in the soils of the roadside plantation of North-Western (NW) Haryana.

The NW India witnessed a green revolution in the late 1970 s by increasing area under agriculture and massive use of chemical fertilizers and pesticides with a monocropping rice-wheat $(\mathrm{RW})$ system (Kalimuthu et al., 2015).

As a repercussion of the green revolution, most of the soils of this area are now facing the challenge of salt accumulation and soil degradation. Though the crop productivity enhanced substantially and made the country self-sufficient in food production (Kesavan and Swaminathan, 2008). However, the deforestation and soil degradation need to be restored for sustainable growth and livelihood.

Extensive roadside plantation as policy encouraged by the Central and State Government of India need to be evaluated on various aspects of maximizing the socioeconomic and ecological benefits. This study evaluated the physicochemical changes and carbon stocking in soils of the roadside plantation and compared it with nearby RW cropping system to develop an understanding of variability in these two land use systems.

\section{Materials and Methods}

\section{Site description}

The study was carried out in NW Haryana, India along the national highway one (NH-1) going towards Delhi, Capital of India. Two different land use viz. roadside plantation and rice-wheat cropping system were compared at five sampling sites in Haryana (Ambala, Kurukshetra, Karnal, Panipatand Sonepat). The location of the sampling sites is given in Figure 1. Road side plantation under this study was extended from Ambala to Sonepat; mainly dominated by Eucalyptus plantation raised and managed by the forest department of Haryana. Some other indigenous species were grown naturally in the study sites (Table $1)$.

Haryana forest department manages roadside plantation such as transplanting, irrigation, pruning, and harvesting. The NW Haryanahas sub-tropical continental monsoon climate and experiences extreme weather conditions. May and June are the hottest months, while December and January are the coldest. The average annual rainfall of NW Haryana is $727 \mathrm{~mm}$ and the distribution is uneven. The selected sites are flat land and cultivated area dominated by intensive RW cropping system and irrigated. The soils of all sampling sites are reclaimed sodic soils and prone to secondary salinization.

\section{Soil sampling}

Soil samples were collected from two different land use, i.e., roadside plantation and RW cropping system of five districts of $\mathrm{NW}$ Haryana. Soil sampling at $0-20 \mathrm{~cm}$ soil depth was done in Feb.-March2015 in both the land use and the sampling locations. From each sampling site, five samples from road side plantation and RW cropping system were collected. During collection of soil samples, 
the upper layer of litter and stones were carefully wiped out. These samples were mixed thoroughly to form a composite, air dried and sieved through a 2-mm sieve for the removal of plant debris and larger particles.

\section{Physicochemical analysis}

Soil samples were collected using a metal core sampler for bulk density (BD) analysis (Blake and Hartage, 1986). Soil pH (soil: water; 1:2) and electrical conductivity (EC) was determined by following standard methods (Jackson, 1967).

Soil textural analysis was performed by the International Pipette Method (Baruah and Barthakur, 1999). SOC was determined by Walkley and Black's method (Jackson 1967). Exchangeable Calcium (Ca) and Magnesium $(\mathrm{Mg})$ were determined by versanate titration method (Cheng and Bray 1951), Sodium (Na) and potassium $(\mathrm{K})$ by flame emission (Jackson, 1967).

\section{Soil carbon stock calculation}

The size of the total carbon stock is calculated by the following method as described by Batjes (1996). The total SOC stock was calculated using the equation given below

$\mathrm{C}$ stock in soil $=\mathrm{C}$ content $\times \mathrm{BD} \times$ Soil depth

Where $\mathrm{C}$ content is presented in $\mathrm{g} \mathrm{C} \mathrm{g}^{-1}, \mathrm{BD}$ in $\mathrm{g} \mathrm{cm}^{-3}$, depth in $\mathrm{m}$ and $\mathrm{C}$ stock in $\mathrm{Mg} \mathrm{ha}^{-1}$.

\section{Statistical Analysis}

Statistical analysis of data (means \pm standard deviation) was computed for each parameter assayed. Tukey post hoc test was used to compare the variations in these soil properties of land use and sampling locations. The significant difference was evaluated at the level of $\mathrm{p}<0.05$. A principal component analysis (PCA) was carried out by transforming the original set of variables into a smaller set of linear combinations called principal components (PC). This statistical analysis was performed by SPSS (version 20.0).

\section{Results and Discussion}

\section{Physicochemical properties of the soil}

The soil texture of all the sampling sites and land use was sandy loam (Sand-72\%, Silt$15 \%$ and Clay-13\%). Soil BD was significantly different in both the land use and ranged from 1.10 to $1.27 \mathrm{~g} \mathrm{~cm}^{-3}$ and 1.15 to $1.43 \mathrm{~g} \mathrm{~cm}^{-3}$ for roadside plantation and RW cropping system respectively (Table 2).

In a roadside plantation, Ambala has recorded minimum BD, i.e., $1.10 \mathrm{~g} \mathrm{~cm}^{-3}$ while Panipat had maximum $\mathrm{BD}$ i.e. $1.27 \mathrm{~g} \mathrm{~cm}^{-3}$. On the other hand, in case of RW cropping system Karnal had minimum BD i.e. $1.15 \mathrm{~g} \mathrm{~cm}^{-3}$ while Ambala had maximum BD $1.43 \mathrm{~g} \mathrm{~cm}^{-3}$ (Table 2).

Soil $\mathrm{pH}$ varied from 6.40 to 7.75 and 7.03 to 7.60 for roadside plantation and RW cropping system, respectively. In a roadside plantation, relatively lower soil $\mathrm{pH}$ was noted in Sonipat (6.40) as compared to the rest of the sampling sites while Kurukshetra had highest $\mathrm{pH}$ (7.55). In case of RW cropping system, lowest soil $\mathrm{pH}$ was in Karnal (7.03) and highest soil $\mathrm{pH}$ was recorded Kurukshetra (7.60).

EC of soil water suspension ranged from 290 to $898 \mu \mathrm{S} \mathrm{cm}^{-1}$ in the roadside plantation and 397 to $710 \mu \mathrm{S} \mathrm{cm}^{-1}$ in the RW cropping system. EC was minimum in Kurukshetra $\left(290 \mu \mathrm{S} \mathrm{cm}^{-1}\right)$ and maximum in Ambala (898 $\mu \mathrm{S} \mathrm{cm} \mathrm{cm}^{-1}$ ) under roadside plantation. However, in RW cropping system, Panipat had minimum EC $\left(397 \mu \mathrm{S} \mathrm{cm}^{-1}\right)$ and Sonipat had maximum EC $\left(710 \mu \mathrm{S} \mathrm{cm}^{-1}\right)$. 
Soil organic carbon (SOC) and carbon stock (CS) in soil

SOC and CS were varied among the sampling sites as well as land use. SOC ranged from $1.03 \%$ to $1.11 \%$ and $0.39 \%$ to $0.57 \%$ in roadside plantation and RW cropping system, respectively (Table 2).

In a roadside plantation, SOC was highest in Karnal (1.11\%) which was $7.21 \%$ higher than the lowest value observed in Ambala (1.03\%). In roadside plantation at Kurukshetra and Karnal, the SOC was similar (Table 2). However, in RW cropping system, SOC in Ambala and Karnal was highest $(0.57 \%)$, which was $31.6 \%$ higher than the lowest value recorded in Sonipat $(0.39 \%)$.

In aroadside plantation, the CS was statistically similar in all the sampling sites except Ambala, which was having lower CS values. Ambala showed reduced CS by $18.6 \%$ from the rest of the sampling sites (Figure 2). In RW cropping system, CS was statistically different in all the studied sampling sites. The highest and lowest values of CS were associated with Ambala (16.1 $\mathrm{Mg} \mathrm{C} \mathrm{ha}^{-1}$ ) and Sonipat ( $9.83 \mathrm{MgC} \mathrm{ha}^{-1}$ ), respectively (Figure 2). The difference in CS between these two sites was $6.27 \mathrm{Mg} \mathrm{C} \mathrm{ha}{ }^{-1}$. The highest decrease in the magnitude of CS compared to Ambala was in Sonipat (38.9\%) followed by Panipat (29.2\%)>Karnal (19.3\%)>Kurukshetra $(11.8 \%)$.

\section{Available Nitrogen (N) and Potassium (K) in soil}

Available $\mathrm{N}$ ranged from 143.0 to $224.8 \mathrm{~kg} \mathrm{ha}^{-}$ ${ }^{1}$ and 146.4 to $290.7 \mathrm{~kg} \mathrm{ha}{ }^{-1}$ in roadside plantation and RW cropping system, respectively. Available $\mathrm{N}$ was highest in Karnal (224.8 and $290.7 \mathrm{~kg} \mathrm{ha}^{-1}$ ) followed by Ambala (201.2 and $282.5 \mathrm{~kg} \mathrm{ha}^{-1}$ ) in roadside plantation and RW cropping system (Table 2).
Overall, available $\mathrm{N}$ in the roadside plantation was lower as compared to RW cropping system. The available $\mathrm{K}$ varied from 240.4 to $308.2 \mathrm{~kg} \mathrm{ha}^{-1}$ and 150.4 to $220.7 \mathrm{~kg} \mathrm{ha}^{-1}$ in roadside plantation and RW cropping system, respectively. In a roadside plantation, Available K was highest in Karnal $(308.2 \mathrm{~kg}$ $\left.\mathrm{ha}^{-1}\right)$ and lowest in Sonipat $\left(240.4 \mathrm{~kg} \mathrm{ha}^{-1}\right)$. In RW cropping system, Available K was highest in Panipat and Ambala with almost similar values (220.7 and $220.4 \mathrm{~kg} \mathrm{ha}^{-1}$ ) and lowest in Karnal $\left(150.4 \mathrm{~kg} \mathrm{ha}^{-1}\right)$.

Effects of land use on exchangeable cations in the soil ( $\mathrm{Na}, \mathrm{Ca}$ and $\mathrm{Mg}$ )

Exchangeable $\mathrm{Na}, \mathrm{Ca}$ and $\mathrm{Mg}$ was determined for all the sampling sites in both the land use. The Na ranged from 35.4 to $56.2 \mathrm{~kg} \mathrm{ha}^{-1}$ and 31.0 to $50.5 \mathrm{~kg} \mathrm{ha}^{-1}$ in roadside plantation and RW cropping system, respectively (Table 3 ). Ambala and Panipat had almost similar $\mathrm{Na}$ contents in the soil for roadside plantation, however, in RW cropping system, Sonipat had highest and Kurukshetra and Karnal had lowest $\mathrm{Na}$ contents. Exchangeable $\mathrm{Ca}$ varied from 0.13 to $0.57 \mathrm{meq}^{-1}$ and 0.16 to $0.43 \mathrm{meq}$ $\mathrm{l}^{-1}$ in roadside plantation and $\mathrm{RW}$ cropping system, respectively.Ca content was highest in Kurukshetra $\left(0.57 \mathrm{meq}^{-1}\right)$ and Sonipat $(0.43$ meq $\left.1^{-1}\right)$ and lowest in Karnal (0.13 and $0.16 \mathrm{meq}^{-1}$ ) in roadside plantation and RW cropping system, respectively. Exchangeable $\mathrm{Mg}$ varied from 0.15 to 0.49 meq $\mathrm{l}^{-1}$ and 0.05 to $0.27 \mathrm{meq}^{-1}$ in roadside plantation and RW cropping system, respectively (Table 3 ). Exchangeable $\mathrm{Mg}$ was highest in Panipat and Karnal $\left(0.49\right.$ and $\left.0.27 \mathrm{meq}^{-1}\right)$ and lowest in Kurukshetra (0.15 meq $\left.\mathrm{l}^{-1}\right)$ and Ambala (0.05 meq $1^{-1}$ ) in roadside plantation and RW cropping system, respectively.

PCA was conducted to reduce the dimension and explain the variance among the sampling sites and land use which was presented in Table 4 and Figure 3. 
Fig.1 Study sites location map in NW Haryana. Study sites marked as star (roadside trees)
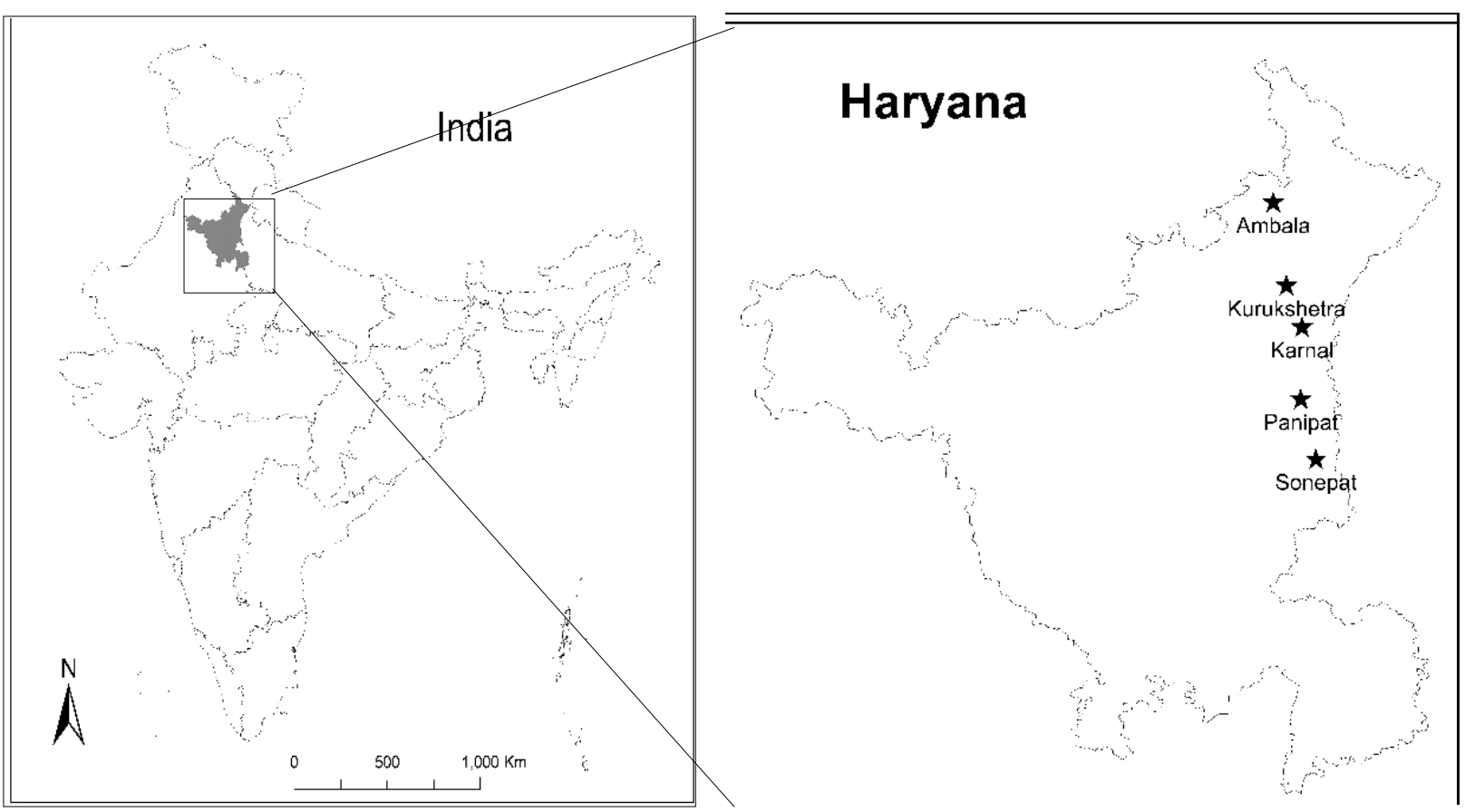

Fig.2 Soil carbon stock up to $20 \mathrm{~cm}$ soil depth under roadside plantation and rice-wheat cropping system. Columns with the same color and letter are not significantly different according to the Tukey test $(\mathrm{P}>0.05)$. A double asterisk means the soil carbon stock among the two land use was statistically significant $(\mathrm{P}>0.01)$. Error bars represent the standard deviation of the means

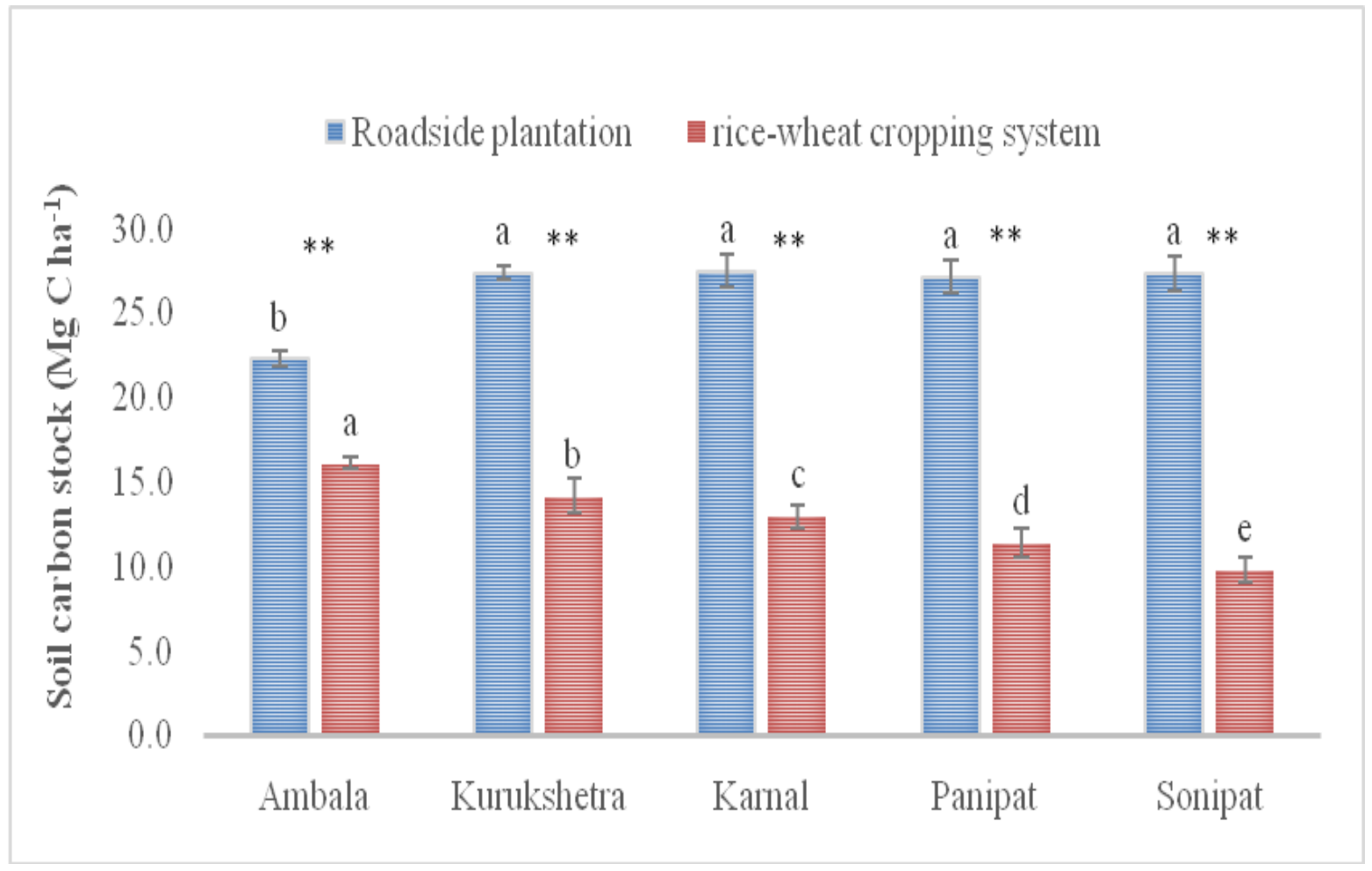


Fig.3 Plots of principal component (PC1 and PC2) for the five locations (Amb-Ambala, KukKurukshetra, Knl-Karnal, Ppt-Panipat and Spt-Sonipat) with two different land use (RP-roadside plantation and RW-rice-wheat cropping system)

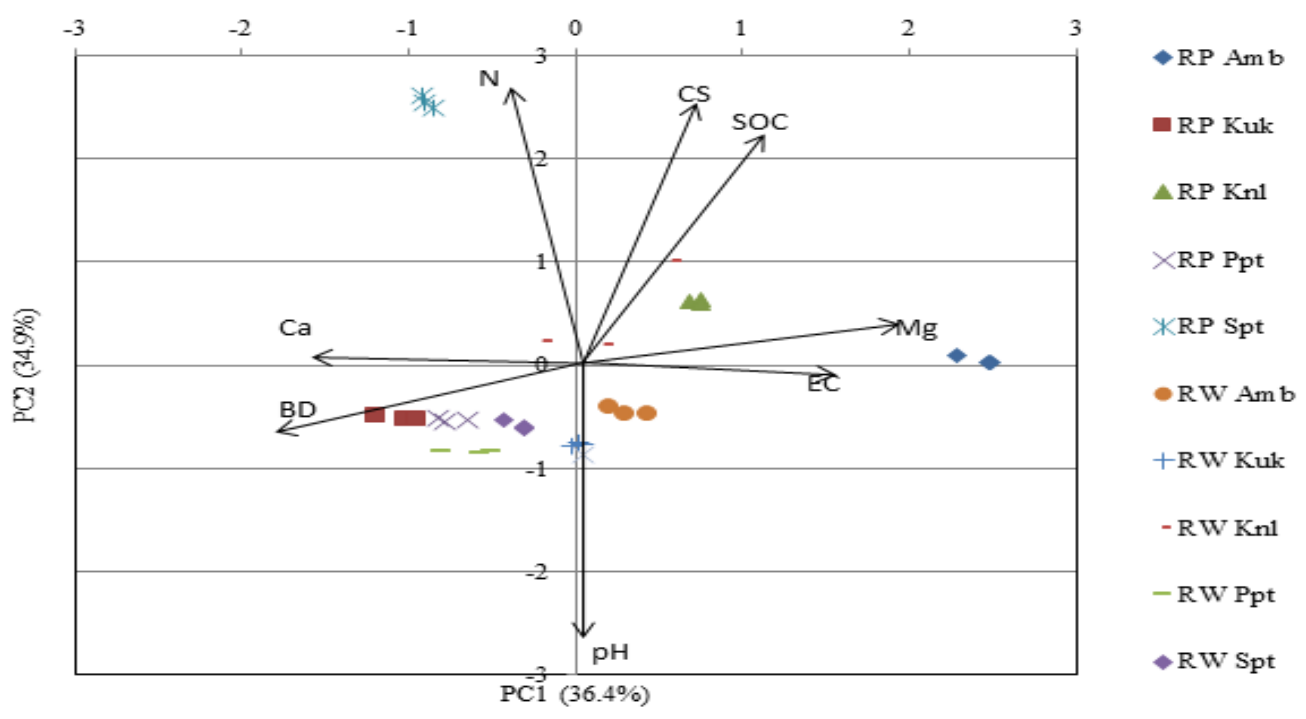

Table.1 Location, soil type and dominant vegetation of the sampling sites

\begin{tabular}{|c|c|c|c|c|}
\hline Site & Location & $\begin{array}{l}\text { Plantation } \\
\text { age } \\
\text { (years) }\end{array}$ & Roadside Plantation & Other vegetation \\
\hline Ambala & $\begin{array}{l}30.29570 \mathrm{~N} \\
076.84648 \mathrm{E}\end{array}$ & 4 & $\begin{array}{l}\text { Eucalyptus tereticornis, } \\
\text { Ziziphus mauritiana, Acacia } \\
\text { tortilis. }\end{array}$ & $\begin{array}{l}\text { Parthinium, Cynodon, } \\
\text { Ageratum, Oxalis, Malvestrum, } \\
\text { Lantana. Chenopodium, } \\
\text { Trifolium, Stellaria media. }\end{array}$ \\
\hline Kurukshetra & $\begin{array}{l}29.92507 \mathrm{~N} \\
076.90521 \mathrm{E}\end{array}$ & 7 & $\begin{array}{l}\text { Eucalyptus tereticornis, } \\
\text { Ziziphus mauritiana, Acacia } \\
\text { tortilis, Azadrirachta indica, } \\
\text { Delonix regia. }\end{array}$ & $\begin{array}{l}\text { Parthenium, Cynodon, } \\
\text { Malvestrum, Ageratum, } \\
\text { Chenopodium, Trifolium. }\end{array}$ \\
\hline Karnal & $\begin{array}{l}29.73954 \mathrm{~N} \\
076.97546 \mathrm{E}\end{array}$ & 16 & $\begin{array}{l}\text { Eucalyptus tereticornis, } \\
\text { Acacia tortilis, Azadrirachta } \\
\text { Indica, Delonix regia, } \\
\text { Syzygium cuminii. }\end{array}$ & $\begin{array}{l}\text { Parthinium, Cynodon, } \\
\text { Ageratum, Oxalis, Malvestrum, } \\
\text { Lantana. Chenopodium, } \\
\text { Trifolium, Stellaria media }\end{array}$ \\
\hline Panipat & $\begin{array}{l}29.41829 \mathrm{~N} \\
076.96869 \mathrm{E}\end{array}$ & 11 & $\begin{array}{l}\text { Azadrirachta Indica, Delonix } \\
\text { regia, Syzygium cuminii, } \\
\text { Mangifera indica. }\end{array}$ & $\begin{array}{l}\text { Parthenium, Cynodon, } \\
\text { Malvestrum, Ageratum, } \\
\text { Nerium. }\end{array}$ \\
\hline Sonepat & $\begin{array}{l}29.15061 \mathrm{~N} \\
077.03703 \mathrm{E}\end{array}$ & 13 & $\begin{array}{l}\text { Eucalyptus tereticornis } \\
\text { camaldulensis, Acacia } \\
\text { tortilis, Azadrirachta indica, } \\
\text { Denolix }\end{array}$ & $\begin{array}{l}\text { Parthenium, Cynodon, } \\
\text { Ageratum, Bougainvillea, } \\
\text { Malvestrum, Stellaria media, } \\
\text { Lantana, Chenopodium, } \\
\text { Trifolium, Oxalis. }\end{array}$ \\
\hline
\end{tabular}

Eucalyptus tereticornis was the dominant species in the roadside plantation, which was planted and managed by the Forest department of Haryana. Eucalyptus tereticornis was planted in two rows (row to row and plant to plant distance was 1.5 and 2 meters, respectively); similar soil texture among the sites had been considered for the effect of the plantation on soil properties and carbon stocking.

Source for botanical name: http://www.haryanaforestflora.in/specimen/view/25 
Table.2 Changes in physico-chemical properties of the soil under roadside plantation and nearby rice-wheat cropping system

\begin{tabular}{|c|c|c|c|c|c|c|c|c|c|}
\hline \multirow[t]{4}{*}{ Site } & \multicolumn{9}{|c|}{ Roadside plantation } \\
\hline & \multirow[t]{3}{*}{$\mathrm{pH}_{2}$} & \multirow[t]{2}{*}{$\mathbf{E C}_{2}$} & \multirow[t]{2}{*}{ BD } & \multicolumn{3}{|c|}{ Particle size distribution } & \multirow[t]{2}{*}{ SOC } & \multirow[t]{2}{*}{$\mathbf{N}$} & \multirow[t]{2}{*}{$\mathbf{K}$} \\
\hline & & & & Sand & Silt & Clay & & & \\
\hline & & $(\mu \mathrm{S} / \mathrm{cm})$ & $\left(\mathrm{g} / \mathrm{cm}^{3}\right)$ & \multicolumn{3}{|c|}{$(\%)$} & $(\%)$ & \multicolumn{2}{|c|}{ (kg/ha) } \\
\hline Ambala & $7.32 \pm 0.07^{\mathrm{cB}}$ & $898.7 \pm 1.53^{\mathrm{aA}}$ & $1.10 \pm 0.01^{\mathrm{bB}}$ & $71.5 \pm 0.46^{\mathrm{a}}$ & $13.8 \pm 1.59^{\mathrm{a}}$ & $14.2 \pm 1.17^{\mathrm{a}}$ & $1.03 \pm 0.02^{\mathrm{CA}}$ & $201.2 \pm 9.05^{\mathrm{bB}}$ & $307.0 \pm 6.11^{\mathrm{aA}}$ \\
\hline Kurukshetra & $7.75 \pm 0.33^{\mathrm{aA}}$ & $290.7 \pm 9.02^{\mathrm{eB}}$ & $1.25 \pm 0.05^{\mathrm{aB}}$ & $72.4 \pm 0.60^{\mathrm{a}}$ & $15.4 \pm 0.76^{\mathrm{a}}$ & $11.6 \pm 0.63^{\mathrm{a}}$ & $1.11 \pm 0.09^{\mathrm{aA}}$ & $196.7 \pm 1.15^{\mathrm{bA}}$ & $281.9 \pm 1.62^{\mathrm{bA}}$ \\
\hline Karnal & $7.34 \pm 0.19^{\mathrm{bA}}$ & $684.3 \pm 5.13^{\mathrm{bA}}$ & $1.24 \pm 0.01^{\mathrm{aA}}$ & $72.0 \pm 0.89^{\mathrm{a}}$ & $12.8 \pm 1.42^{\mathrm{a}}$ & $12.7 \pm 2.19^{\mathrm{a}}$ & $1.11 \pm 0.08^{\mathrm{aA}}$ & $224.8 \pm 4.53^{\mathrm{aB}}$ & $308.2 \pm 7.10^{\mathrm{aA}}$ \\
\hline Panipat & $7.14 \pm 0.08^{\mathrm{dB}}$ & $397.0 \pm 6.08^{\mathrm{dB}}$ & $1.27 \pm 0.03^{\mathrm{aA}}$ & $74.1 \pm 0.54^{\mathrm{a}}$ & $14.0 \pm 0.24^{\mathrm{a}}$ & $11.4 \pm 0.60^{\mathrm{a}}$ & $1.07 \pm 0.02^{\mathrm{bA}}$ & $146.4 \pm 4.53^{\mathrm{CB}}$ & $270.7 \pm 0.61^{\mathrm{bA}}$ \\
\hline \multirow[t]{2}{*}{ Sonipat } & $6.40 \pm 0.04^{\mathrm{eB}}$ & $515.0 \pm 5.00^{\mathrm{cB}}$ & $1.26 \pm 0.04^{\mathrm{aA}}$ & $72.5 \pm 0.62^{\mathrm{a}}$ & $14.5 \pm 0.66^{\mathrm{a}}$ & $12.7 \pm 1.02^{\mathrm{a}}$ & $1.08 \pm 0.05^{\mathrm{bA}}$ & $143.0 \pm 2.12^{\mathrm{CB}}$ & $240.4 \pm 0.71^{\mathrm{cA}}$ \\
\hline & \multicolumn{9}{|c|}{ RW cropping system } \\
\hline Ambala & $7.60 \pm 0.13^{\mathrm{aA}}$ & $579.3 \pm 8.50^{\mathrm{dB}}$ & $1.43 \pm 0.45^{\mathrm{aA}}$ & $70.6 \pm 0.50^{\mathrm{a}}$ & $14.0 \pm 1.08^{\mathrm{a}}$ & $14.7 \pm 0.56^{\mathrm{a}}$ & $0.57 \pm 0.03^{\mathrm{aB}}$ & $282.5 \pm 0.44^{\mathrm{aB}}$ & $220.4 \pm 0.55^{\mathrm{aB}}$ \\
\hline Kurukshetra & $7.54 \pm 0.04^{\mathrm{bB}}$ & $659.0 \pm 10.2^{\mathrm{bB}}$ & $1.28 \pm 0.06^{\mathrm{bA}}$ & $70.8 \pm 0.55^{\mathrm{a}}$ & $13.8 \pm 0.66^{\mathrm{a}}$ & $14.4 \pm 0.58^{\mathrm{a}}$ & $0.56 \pm 0.03^{\mathrm{aB}}$ & $146.4 \pm 4.53^{\mathrm{dB}}$ & $180.4 \pm 0.52^{\mathrm{bB}}$ \\
\hline Karnal & $7.03 \pm 0.03^{\mathrm{dB}}$ & $520.3 \pm 9.29^{\mathrm{eB}}$ & $1.15 \pm 0.05^{\mathrm{cB}}$ & $70.6 \pm 0.62^{\mathrm{a}}$ & $13.1 \pm 0.99^{\mathrm{a}}$ & $14.0 \pm 0.77^{\mathrm{a}}$ & $0.57 \pm 0.03^{\mathrm{aB}}$ & $290.7 \pm 1.11^{\mathrm{aA}}$ & $150.4 \pm 0.52^{\mathrm{cB}}$ \\
\hline Panipat & $7.55 \pm 0.09^{\mathrm{bA}}$ & $603.0 \pm 6.08^{\mathrm{cA}}$ & $1.25 \pm 0.03^{\mathrm{bB}}$ & $72.0 \pm 0.11^{\mathrm{a}}$ & $13.3 \pm 0.79^{\mathrm{a}}$ & $13.6 \pm 0.45^{\mathrm{a}}$ & $0.46 \pm 0.02^{\mathrm{bB}}$ & $190.8 \pm 4.53^{\mathrm{CA}}$ & $220.7 \pm 1.15^{\mathrm{aB}}$ \\
\hline Sonipat & $7.33 \pm 0.02^{\mathrm{cA}}$ & $710.7 \pm 3.05^{\mathrm{aA}}$ & $1.26 \pm 0.01^{\mathrm{bA}}$ & $73.1 \pm 0.06^{\mathrm{a}}$ & $13.0 \pm 0.29^{\mathrm{a}}$ & $13.4 \pm 0.50^{\mathrm{a}}$ & $0.39 \pm 0.03^{\mathrm{cB}}$ & $221.3 \pm 12.7^{\mathrm{bA}}$ & $190.0 \pm 0.28^{\mathrm{bB}}$ \\
\hline
\end{tabular}

Values within a column in the sites of same landuse followed by the same lowercase letters are not significantly different (P <0.05); Values within a column in same the sites across the landuse followed by the same uppercase letters are not significantly different (P <0.05); BD-bulk density and SOC- soil organic carbon. \#means datawere not analyzed for significance among the landuse.

Table.3 Changes in cations, sodium adsorption ratio and cation exchange capacity of the soil under roadside plantation and nearby RW cropping system

\begin{tabular}{|l|c|c|c|}
\hline \multirow{2}{*}{ Site } & \multicolumn{3}{|c|}{ Roadside plantation } \\
\hline Ambala & $\mathrm{Na}(\mathbf{k g} / \mathbf{h a})$ & $\mathrm{Ca}(\mathbf{m e q} / \mathbf{l})$ & $\mathrm{Mg}(\mathbf{m e q} / \mathbf{l})$ \\
\hline Kurukshetra & $56.12 \pm 0.10^{\mathrm{aA}}$ & $0.24 \pm 0.04^{\mathrm{cB}}$ & $0.14 \pm 0.01^{\mathrm{cA}}$ \\
\hline Karnal & $35.77 \pm 0.07^{\mathrm{cA}}$ & $0.57 \pm 0.02^{\mathrm{aA}}$ & $0.15 \pm 0.01^{\mathrm{cB}}$ \\
\hline Panipat & $35.36 \pm 0.15^{\mathrm{cA}}$ & $0.13 \pm 0.01^{\mathrm{dB}}$ & $0.23 \pm 0.02^{\mathrm{bA}}$ \\
\hline Sonipat & $55.28 \pm 0.04^{\mathrm{aA}}$ & $0.24 \pm 0.02^{\mathrm{cB}}$ & $0.49 \pm 0.02^{\mathrm{aA}}$ \\
\hline & $46.02 \pm 0.02^{\mathrm{bB}}$ & $0.47 \pm 0.01^{\mathrm{bA}}$ & $0.19 \pm 0.01^{\mathrm{cA}}$ \\
\hline Ambala & $\mathbf{R W}$ cropping system $^{\mathrm{b}}$ & \\
\hline Kurukshetra & $35.3 \pm 0.04^{\mathrm{bB}}$ & $0.28 \pm 0.02^{\mathrm{dA}}$ & $0.05 \pm 0.01^{\mathrm{eB}}$ \\
\hline Karnal & $31.1 \pm 0.12 \mathrm{~b}^{\mathrm{cB}}$ & $0.39 \pm 0.01^{\mathrm{bB}}$ & $0.23 \pm 0.01^{\mathrm{bA}}$ \\
\hline Panipat & $31.0 \pm 0.01 \mathrm{~b}^{\mathrm{cB}}$ & $0.16 \pm 0.01^{\mathrm{eA}}$ & $0.27 \pm 0.03^{\mathrm{aB}}$ \\
\hline Sonipat & $33.5 \pm 0.05^{\mathrm{bB}}$ & $0.32 \pm 0.03^{\mathrm{cA}}$ & $0.15 \pm 0.01^{\mathrm{dB}}$ \\
\hline
\end{tabular}

Values within a column in the sites of same landuse followed by the same lowercase letters are not significantly different $(\mathrm{P}<0.05)$; Values within a column in the same sites across the landuse followed by the same uppercase letters are not significantly different $(\mathrm{P}<0.05)$; SAR- sodium adsorption ratio and CEC-cation exchange capacity 
Table.4 Rotated component matrix of the PCA explaining the variance acquired by different soil properties for $\mathrm{PC} 1$ and $\mathrm{PC} 2$

\begin{tabular}{|c|c|c|}
\hline & \multicolumn{2}{|c|}{ Rotated Component $^{\text {a }}$} \\
\hline & PC1 & PC2 \\
\hline $\mathrm{pH}_{2}$ & 0.047 & -0.865 \\
\hline $\mathrm{EC}\left(\mu \mathrm{S} \mathrm{cm} \mathrm{cm}^{-1}\right)$ & 0.802 & -0.015 \\
\hline Bulk density $\left(\mathrm{g} \mathrm{cm}^{-3}\right)$ & -0.750 & -0.139 \\
\hline SOC (\%) & 0.594 & 0.704 \\
\hline Carbon stock (Mg C ha') & 0.404 & 0.854 \\
\hline $\mathbf{N}\left(\mathrm{kg} \mathrm{ha}^{-1}\right)$ & -0.178 & 0.891 \\
\hline $\mathrm{Ca}\left(\operatorname{meq~l^{-1})}\right.$ & -0.624 & -0.002 \\
\hline $\operatorname{Mg}\left(\operatorname{meq~l^{-1}}\right)$ & 0.874 & 0.068 \\
\hline Variance $(\%)$ & 36.4 & 34.9 \\
\hline
\end{tabular}

Principal component 1 (PC1) and principal component 2 (PC2) accounted for $36.4 \%$ and $34.9 \%$ of the total variation, respectively. The PC scores on this axis were well separated by sampling sites and soil properties in both the land use, especially along PC1 (Figure 3).

EC and $\mathrm{Mg}$ were grouped along PC1.In contrast, $\mathrm{BD}$ and $\mathrm{Ca}$ were separated negatively along PC1. SOC, N and CS were grouped along PC2; Soil $\mathrm{pH}$ was separated negatively along PC2. EC, SOC, CS and $\mathrm{Mg}$ were positively correlated with $\mathrm{PC} 1$, similarly SOC, CS and $\mathrm{N}$ were positively correlated with PC2 (Table 3).

\section{Physicochemical properties of the soil}

Soil physicochemical properties influenced by the land use and management practices due to several factors. Sandy loam texture requires more frequent irrigation and fertilization than soils with a higher concentration of clay. Sandy loam soils are often deficient in specific micronutrients and may need additional fertilization to support healthy plant growth. However, micronutrient status in the soils was not targeted in this study. Higher BD in RW cropping system might be due to low organic matter input and compaction by the heavy vehicles like tractors (Datta et al., 2015; Chaudhari et al., 2015a).

The lower value of BD at roadside plantation might be due to higher organic input in the form of leaf and twig litter as well as low traffic of heavy vehicles.

Lower soil $\mathrm{pH}$ in $\mathrm{RW}$ cropping system might be due to excessive use of chemical fertilizers and flooding in rice crop that may leach the basic cations. In contrast, roadside plantation receives washed salts from the agricultural field that might increase the $\mathrm{EC}$ and $\mathrm{pH}$ of the soil. Lowest soil pH (6.40) was observed in Sonipat. This might be due to the production of organic acids during the decomposition of organic litter and exudation from the root of the plantation. Higher $\mathrm{pH}$ (7.75) in Kurukshetra in both the land use might be due to less land cover by plantation and higher evapotranspiration as the plantation are just seven years of age and canopy is not sufficient to protect the evapotranspiration loss which causes accumulation of salts on the surface. These observations are in concurrence with the findings of Datta et al., (2015) and Srivastava et al., (2016). 


\section{Variation in SOC and CS in soils}

Eucalyptus dominates in the roadside plantation and plantation age varying with sampling sites. Higher SOC and CS in roadside plantation might be due to greater organic input SOC as leaf and bark (mainly from Eucalyptus). Plantation age with intensive root system might be the reason for highest SOC accumulation in Karnal under roadside plantation. Also, the translocation of dissolved organic carbon from the agriculture field to the roadside plantation also contributes to the SOC buildup.

The carbon fixed by the plant is the primary source of organic matter inputs in the soil both from above and below ground components of plants. The changes in microclimate under tree canopy (soil moisture, temperature, light, humidity, etc.), the proliferation of root system and enhanced biological activity also favor the carbon stock in the soil (Chaudhari et al., 2015b).

In a roadside plantation, the CS was statistically similar in all the sampling sites except Ambala, which was having lower CS values. This might be due to a disturbance in the soil for broadening the road area and new plantation just four years back. The plantation age plays a crucial role in sequestering carbon by adding more organic inputs and controlling the secretion of organic acids from the root exudates.

The higher age of the Eucalyptus plantation in Karnal (16 years), Sonipat (13 years) and Panipat (11 years) might have played a role in the production of recalcitrant compounds in the form of rhizodeposition that led to the conversion of more SOC in the passive pool in deeper soil layers. These results are in agreement with the previous studies by Chaudhari et al., (2014), Datta et al., (2015) and Chaudhari et al., (2015b).

\section{Changes in available $\mathrm{N}$ and $\mathrm{K}$ in soil}

Litter inputs from above and below ground biomass not only sequester soil carbon but also play a pivotal role in biogeochemical cycling of the nutrients for plant growth. Higher available nitrogen in the RW cropping system was due to excessive application of nitrogenous fertilizer. $\mathrm{K}$ is a highly mobile element that dissolves easily and the $\mathrm{K}$ ions in solution diffuse through the soil from areas of high $\mathrm{K}$ concentrations to areas of low $\mathrm{K}$ concentration. The rhizosphere usually has low $\mathrm{K}$ levels due to the uptake of $\mathrm{K}$ ions from the soil solution into the roots and subsequent accumulation into different parts of the plants. This might be the reason for low $\mathrm{K}$ in the RW cropping system in all the sites as compared to Roadside plantation.

\section{Effects of land use on exchangeable cations in the soil ( $\mathrm{Na}, \mathrm{Ca}$ and $\mathrm{Mg}$ )}

Exchangeable $\mathrm{Na}, \mathrm{Ca}$ and $\mathrm{Mg}$ plays a crucial role in nutrient cycling and carbon dynamics. The translocation and accumulation of these cations were controlled by the soil moisture and texture. Also, the higher cations in the soil might be due to the parent material brought by the rivers in the alluvium plains of the Trans-Ganges. Higher cations in roadside plantation might be due to movement of soluble salts from RW cropping system to the roadside plantation. Ca content was highest in Kurukshetra $\left(0.57 \mathrm{meq} \mathrm{l}^{-1}\right)$ and Sonipat $(0.43$ meq $1^{-1}$ ) in roadside plantation and RW cropping system, respectively. This might be due to favorable conditions and modification of the micro-environment at the sampling location. Higher $\mathrm{Mg}$ hinders the availability and uptake of $\mathrm{K}$ in the soil and has an antagonistic relationship. This also has been confirmed by our results.

Principal component 1 (PC1) and principal component 2 (PC2) accounted for 36.4 and 
$34.9 \%$ of the total variation, respectively. The PC scores on this axis were well separated by sampling sites and soil properties in both the land use, especially along PC1. The bulk density explains the majority of the site specific variability. On the PC 1, Roadside plantation (Karnal and Soinipat) and the rest of the sampling sites are separated as extremes of land use; the proximity of the RW cropping system in Karnal reflects their level of change as a consequence of land use and micro-environment the sampling sites.

The selected roadsides were among the busiest roadsides of the country (National Highway One), heavily loaded with traffic causes severe vehicular pollution by interacting with the precipitation and finally polluting the soil and ground water. Our study provides an evidence of the pivotal role of the roadside plantation on physicochemical properties of the soil and soil carbon stocking as compared to RW cropping system near the roadside. The mean carbon stock across the sites was almost double in roadside plantation as compared to RW cropping System. Thus, it may be concluded that roadside plantation plays a crucial role in improving the soil environment and has potential to sequester carbon in the soil. For multifunctional benefits as well as a low-cost tool in mitigating climate change, roadside plantation should be encouraged in a semi-arid environment.

\section{Acknowledgement}

The authors are thankful to the Director of Institute of Environmental Studies, Kurukshetra University, Kurukshetra, Haryana, India for funding the research and providing the laboratory facilities. We thankfully acknowledge the help and support of forest officers, Department of Forest, Kurukshetra for providing the information related to the roadside plantation.

\section{References}

Baruah TC, Barthakur HP (1999) A Text Book of Soil Analysis, Vikas Publishing House, New Delhi, India.

Batjes NH (1996) Total carbon and nitrogen in the soils of the world. Eur J Soil Sci 47:151-163.

Blake GR, Hartge KH (1986) Bulk density. A. Klute (Ed.), Methods of soil analysis. Part I. Physical and mineralogical methods, Soil Science Society of America, Inc., Madison, WI 363-376.

Chaudhari SK, Bardhan G, Kumar P, Singh R, Mishra AK, Rai P, Singh K, and Sharma DK (2015a) Short-term tillage and residue management impact on physical properties of a reclaimed sodic soil. J. Indian Soc. Soil Sci. 63 (1):3038.

Chaudhari SK, Kumar P, Mishra AK, Singh K, Rai P, Singh R, and Sharma DK (2015b) Labile carbon fractions buildup and dynamics under vertical stratification of Populus deltoides and Eucalyptus tereticornis based agroforestry systems in Trans-Gangetic Plains of India. Ann. Agric. Res. 36(1):1-9.

Chaudhari SK, Kumar P, Singh K, Mishra AK, Rai P, Singh R, and Sharma DK (2014) Aggregate fractions and organic carbon dynamics in partially reclaimed sodic soils growing Eucalyptus tereticornis. Journal of Soil Salinity and Water Quality 6(2): 96-100.

Datta A, Basak N, Chaudhari SK, Sharma DK (2015) Soil properties and organic carbon distribution under different land uses in reclaimed sodic soils of NorthWest India. Geoderma Regional 4:134146.

Jackson ML (1967) Soil chemical analysis. Prentice Hall of India Pvt. Ltd., New Delhi, 1967. 
Kalimuthu I, Roy D, Joshi PK (2015) Supplyside dynamics of chickpeas and pigeon peas in India. IFPRI Discussion Paper 1454.

Kesavan PC, Swaminathan MS (2008) Strateg ies and models for agricultural sustainability in developing Asian countries. Phil. Trans. R. Soc. B. 363: 877-891.

Kumar P, Chaudhari SK, Mishra AK, Singh K, Rai P, Singh R, Sharma DK (2014) Labile carbon dynamics and soil amelioration in six-year old Eucalyptus tereticornis plantation in sodic soils. Journal of Soil Salinity and Water Quality 6(2): 91-95.

Shukla PK (2009) Nutrient dynamics of Teak plantations and their impact on soil
productivity-A case study from India. XIII World Forestry Congress, Buenos Aires, Argentina, pp 11.

Srivastava K, Jat HS, Meena MD, Choudhary M, Mishra AK, Chaudhari SK (2016) Long term impact of different cropping systems on soil quality under silty loam soils of Indo-Gangetic plains of India. Journal of Applied and Natural Science8 (2): 584-587.

Tian H, Banger K, Bo T, Dadhwal VK (2014) History of land use in India during 1880-2010: large-scale land transformations reconstructed from satellite data and historical archives. Global Planet Change 121:7888.

\section{How to cite this article:}

Rahul Arya, Ajay Kumar Mishra and Smita Chaudhry. 2018. Variation in Soil Properties and Carbon Stocks under Roadside Plantation and Rice-Wheat Cropping System in North Western Haryana, India. Int.J.Curr.Microbiol.App.Sci. 7(04): 1939-1949. doi: https://doi.org/10.20546/ijcmas.2018.704.222 